\title{
Analisis Video Share to Video Comments Ratio Tiktok Pada 5 Merek Smartphone Terlaris di Indonesia
}

\author{
I Komang Agus Susila Yasa \\ kkomang172@gmail.com
}

\begin{abstract}
Tiktok is an application that is able to change the way of using social media before with their uniqueness, namely videos that are 15-60 seconds long. The Tiktok application is not only a video, but also contains music, filters, and other interesting features. The Tiktok application was launched globally by a Chinese company with a parent company called ByteDance. It is estimated that Indonesia accounts for about $11 \%$ of total downloads globally and makes Indonesia one of the countries with the largest Tiktok application users in the world. Then with such a large number of Tiktok downloaders, it can provide opportunities for users such as smartphone brands to make this Tiktok platform or application their social media marketing platform. There are 5 smartphone brands in Indonesia that use Tiktok as their marketing platform, including: Xiaomi Indonesia, Vivo Indonesia, Oppo Indonesia, Samsung Indonesia and Realme Indonesia. This research was made using an exploratory exploratory method, with the aim of knowing how the credibility or performance of the Tiktok account of the 5 bestselling smartphone brands in Indonesia. Then the results of this study show that the Oppo Indonesia brand has better performance credibility compared to other smartphone brands.
\end{abstract}

\begin{abstract}
ABSTRAK
Tiktok merupakan salah satu aplikasi yang mampu mengubah cara pemakaian media sosial sebelumnya dengan keunikan mereka yakni video berdurasi 15 - 60 detik. Aplikasi Tiktok bukan hanya berupa video, tetapi juga berisi musik, filter, serta fitur menarik lainnya. Aplikasi Tiktok ini diluncurkan secara global oleh perusahaan asal Tiongkok dengan induk perusahaan bernama ByteDance. Diperkirakan Indonesia menyumbang sekitar $11 \%$ dari total unduhan secara global dan menjadikan Indonesia sebagai salah satu negara dengan pengguna aplikasi Tiktok terbesar di dunia. Kemudian dengan jumlah pengunduh Tiktok sebesar itu dapat memberikan peluang bagi pengguna seperti merek smartphone untuk menjadikan platform atau aplikasi Tiktok ini sebagai platform social media marketing mereka. Adapun 5 merek smartphone di Indonesia yang memanfaatkan Tiktok sebagai platform marketing mereka, diantaranya : Xiaomi Indonesia, Vivo Indonesia, Oppo Indonesia, Samsung Indonesia dan Realme Indonesia. Penelitian ini dibuat menggunakan metode eksploratif eksploratif, dengan tujuan untuk mengetahui bagaimana kredibilitas atau performa dari akun Tiktok 5 merek smartphone terlaris di Indonesia. Kemudian hasil dari penelitian ini menunjukan bahwa merek Oppo Indonesia memiliki kredibilitas performa yang lebih baik dibandingkan dengan merek smartphone yang lainnya.
\end{abstract}


Keyword : Social Media Marketing ; Social Media Tiktok ; Video Share to Video Comments Ratio ; Merek Smartphone Indonesia ; Credibility Account Tiktok ; Platform Social Media Marketing ; Eksploratif Kuantitatif Method.

\section{PENDAHULUAN}

Teknologi informasi merupakan suatu teknologi yang digunakan untuk mengolah sebuah data, termasuk seperti memproses data, mendapatkan data serta menyimpan data dalam berbagai hal untuk dapat memberikan sebuah informasi yang berkualitas, seperti informasi yang relevan, akurat, dan cepat. Teknologi informasi saat ini sudah telah berkembang cukup jauh, yang mana membuat suatu perubahan dalam hidup kita, seperti perubahan dari segi berkomunikasi, segi berbisnis maupun dari segi pembelajaran. Kemudian salah satu contoh perkembangan teknologi informasi adalah dengan munculnya berbagai media sosial. Media sosial sendiri dapat memberikan pengaruh yang sangat besar terhadap kehidupan kita, seperti memberikan kita kemudahan untuk berkomunikasi dengan orang lain secara dua arah dan secara bersamaan.

Seiring dengan berkembangnya teknologi komunikasi seperti halnya penggunaan media sosial, telah memberikan dampak baik bagi banyak orang seperti memperluas akses dan memberikan kebebasan dalam melakukan komunikasi baik dari jarak yang jauh dan dengan akses yang cepat. Pada awalnya, teknologi komunikasi hanya digunakan untuk pelayanan radio dan bertulis surat semata, namun sekarang teknologi komunikasi sudah berkembang dengan sangat pesat, kita bahkan dapat melakukan panggilan video secara tatap muka yang berlangsung secara bersamaan. Dan seiring waktu, mulai bermunculan aplikasi - aplikasi yang dapat memudahkan kita dalam melakukan komunikasi, contohnya adalah aplikasi Tiktok. Tiktok merupakan salah satu aplikasi yang dapat mengubah cara pemakaian media sosial sebelumnya dengan keunikan mereka yakni video berdurasi 15 - 60 detik (Firamadhina and Krisnani 2021). Aplikasi Tiktok bukan hanya berupa video, tetapi juga berisi musik, filter, serta fitur menarik lainnya. Aplikasi Tiktok ini diluncurkan secara global oleh perusahaan asal Tiongkok dengan induk perusahaan bernama ByteDance.

Tiktok merupakan salah satu aplikasi media sosial terpopuler untuk beberapa tahun ini. Total unduhan aplikasi Tiktok pada tahun 2020 mencapai sekitar 63,3 juta kali unduhan (Dewa and Safitri 2021). Diperkirakan Indonesia menyumbang sekitar $11 \%$ dari total unduhan secara global dan menjadikan Indonesia sebagai salah satu negara dengan pengguna aplikasi Tiktok terbesar di dunia. Kemudian dengan jumlah pengunduh Tiktok sebesar itu dapat memberikan peluang bagi pengguna seperti merek smartphone untuk menjadikan platform atau aplikasi Tiktok ini sebagai platform social media marketing mereka. Hampir semua akun perusahaan atau orang - orang terkenal ada di Tiktok, seperti contohnya merek smartphone di Indonesia. Adapun 5 Merek Smartphone Terlaris di Indonesia, diantaranya adalah : Xiaomi Indonesia, Vivo Indonesia, Samsung Indonesia, Oppo Indonesia, dan Realme Indonesia ("Daftar 5 Merek Smartphone Terlaris Di Indonesia, Xiaomi Nomor 1" 2021).

Penelitian ini dilakukan menggunakan metode eksploratif kuantitatif, dan metode ini digunakan untuk menghitung atau mencari nilai tertentu dengan menggunakan rasio - rasio yang ada pada Tiktok. Pada penelitian (Permana and Meinarni 2021) dijelaskan bahwa terdapat 
sekitar 17 rasio pada 7 variable yang terdapat pada Tiktok dan signifikan digunakan untuk media ukur kredibilitas dari akun yang ada. Penelitian ini hanya akan berfokus pada menghitung kredibilitas Video Share to Video Comments Ratio pada 5 Merek Smartphone Terlaris di Indonesia. Tujuan dari penelitian ini adalah untuk mencari dan mengetahui kredibilitas performa dari akun Tiktok 5 Merek Smartphone Terlaris di Indonesia menggunakan Video Share to Video Comments Ratio.

\section{TINJAUAN PUSTAKA}

Perkembangan teknologi komunikasi hingga saat ini sudah sangat berkembang dibandingkan 10 tahun lalu, mulai dari memudahkan dalam komunikasi, memudahkan dalam menyampaikan informasi dan sebagainya. Perkembangan yang disebut dapat dilihat dari munculnya aplikasi aplikasi media sosial yang marak digunakan oleh berbagai kalangan. Beberapa aplikasi yang diminati oleh masyarakat khususnya di Indonesia adalah Tiktok, Whatsapp, Twitter, Facebook, Instagram, Youtube dan lain sebagainya. Aplikasi - aplikasi media sosial tersebut dapat menarik minat pengguna dan merubah pandangan kita tentang sebuah aplikasi.

Media sosial TikTok merupakan aplikasi media sosial yang sedang trend pada saat pandemic sekarang ini dibandingkan dengan aplikasi media sosial lain yang sudah digunakan oleh banyak orang (Oktaheriyani, Wafa, and Shadiqien 2020). TikTok merupakan sebuah platform media sosial yang memberikan kemudahan untuk pemakainya dalam menciptakan video yang berdurasi 15 sampai 60 detik (Rahardaya and Irwansyah 2021). Video tersebut juga dapat dikombinasikan dengan ratusan macam pilihan fitur seperti musik, filter dan beberapa efek lainnya. Tiktok memiliki banyak keuntungan, seperti menyediakan informasi yang cepat dan akurat tanpa perlu menyediakan biaya tinggi, serta dapat dilakukan dalam kurun waktu yang sangat singkat (Khanifah 2021). Aplikasi Tiktok juga memiliki keunikan dalam segi tampilan awal ketika menggunakan aplikasi Tiktok, yaitu terdapat FYP atau for your page dengan mengambil konten dari video yang paling sering pengguna tonton dalam aplikasi Tiktok dan menampilkannya di tampilan awal pengguna.

Dalam media sosial TikTok terdapat sangat banyak konten kreator yang membuat sebuah konten yang menarik, menghibur dan inspiratif (Kesuma and Tamburian 2021). Kemudian juga terdapat konten yang kurang baik atau negatif didalam aplikasi media sosial Tiktok. Dengan banyaknya konten yang dapat di lihat menjadikan Tiktok sebagai salah satu media sosial terpopuler tidak hanya di Indonesia tetapi juga dibeberapa negara besar.

Saat ini aplikasi Tiktok menjadi salah satu platform media sosial yang banyak digunakan untuk melakukan kegiatan berbisnis seperti digital marketing (Priatama et al. 2021). Konten video yang dibuat oleh pebisnis dalam aplikasi Tiktok bisa muncul dalam tampilan awal seorang pengguna Tiktok, dengan begitu konten dapat dilihat oleh banyak orang sehingga memberikan kesempatan bagi pembisnis untuk mendapatkan seorang pelanggan.

Terdapat banyak media sosial yang dapat digunakan sebagai kegiatan digital marketing, tetapi penggunaan aplikasi Tiktok terlihat lebih memiliki pengaruh dalam kegiatan marketing sehingga dapat menampilkan kualitas dari akun. Kredibilitas sebuah akun sangat penting untuk 
diukur, dapat menggunakan metode sistematis seperti pengukuran dari performa sebuah akun atau sebagainya. Pengukuran performa sebuah akun dilandaskan oleh skala pengukuran yang tertuang dalam sebuah rasio.

\section{METODE PENELITIAN}

Penelitian ini dibuat menggunakan metode eksploratif eksploratif, dengan tujuan untuk mengetahui bagaimana kredibilitas atau performa dari akun Tiktok 5 merek smartphone terlaris di Indonesia. Metode eksploratif adalah salah satu metode yang digunakan dalam penelitian ilmiah dengan melakukan pengumpulan data - data untuk menjawab permasalahan yang menjadi tujuan dari penelitian (Mudjiyanto 2018).

Tujuan dari penelitian yang dibuat adalah untuk dapat mengetahui nilai kredibilitas performa akun Tiktok 5 merek smartphone terlaris di Indonesia. Untuk menyelesaikan dan mendapatkan nilai kredibilitas terbaik dari akun tiktok, terdapat beberapa langkah yang harus dilakukan untuk menyelesaikan dan mendapatkan nilai kredibilitas tersebut. Dengan dilakukannya langkah - langkah tersebut, nantinya akan diketahui peringkat pertama akun Tiktok dari 5 merek smartphone yang terlaris di Indonesia. Langkah - langkah yang perlu dilakukan dalam penelitian yang dibuat ini, yaitu :

\subsection{Melakukan Eksplorasi Pada Halaman Website Untuk Menentukan Objek yang} Akan Dianalisa.

Langkah pertama dalam melakukan penelitian adalah dengan melakukan pencarian atau eksplorasi pada beberapa halaman website tentang objek yang akan diteliti. Kemudian setelah eksplorasi selesai dilakukan, sehingga ditemukanlah nama - nama merek smartphone terlaris di Indonesia yang akan dijadikan objek untuk dianalisa. Dan setelah selesai mengambil objek yang diinginkan pada halaman website, maka dilanjutkan dengan mencari nama - nama akun Tiktok dari setiap merek smartphone yang sudah ditentukan tadi, dan juga memastikan agar semua objek atau setiap merek smartphone memiliki akun pada aplikasi Tiktok.

\subsection{Menghitung Nilai Rata-Rata Variable Dari 5 Merek Smartphone Terlaris di Indonesia.}

Langkah kedua adalah melakukan hitungan nilai variable video share dan video comments dari masing - masing akun Tiktok. Variabel adalah atribut atau sebuah nilai yang memiliki banyak variasi, variabel sendiri dapat berupa angka dalam rasio, nominal atau skala. Variabel sering dijabarkan sebagai objek dalam pengamatan penelitian, dan juga sering disebut faktor, dimana faktor tersebut berperan dalam penelitian atau gejala yang akan diteliti (Riadi 2020). Kemudian untuk mencari nilai rata - rata dari variabel nilai video share dan variabel nilai video comments dilakukan dengan cara mendapatkan dan mengambil minimal 10 postingan terbaru dari setiap akun Tiktok, kemudian setelah itu, setiap nilai variabel tersebut ditambahkan kemudian dibagi sesuai dengan banyak postingan yaitu 10 , sehingga didapatkan nilai rata - rata dari masing masing variabel. 


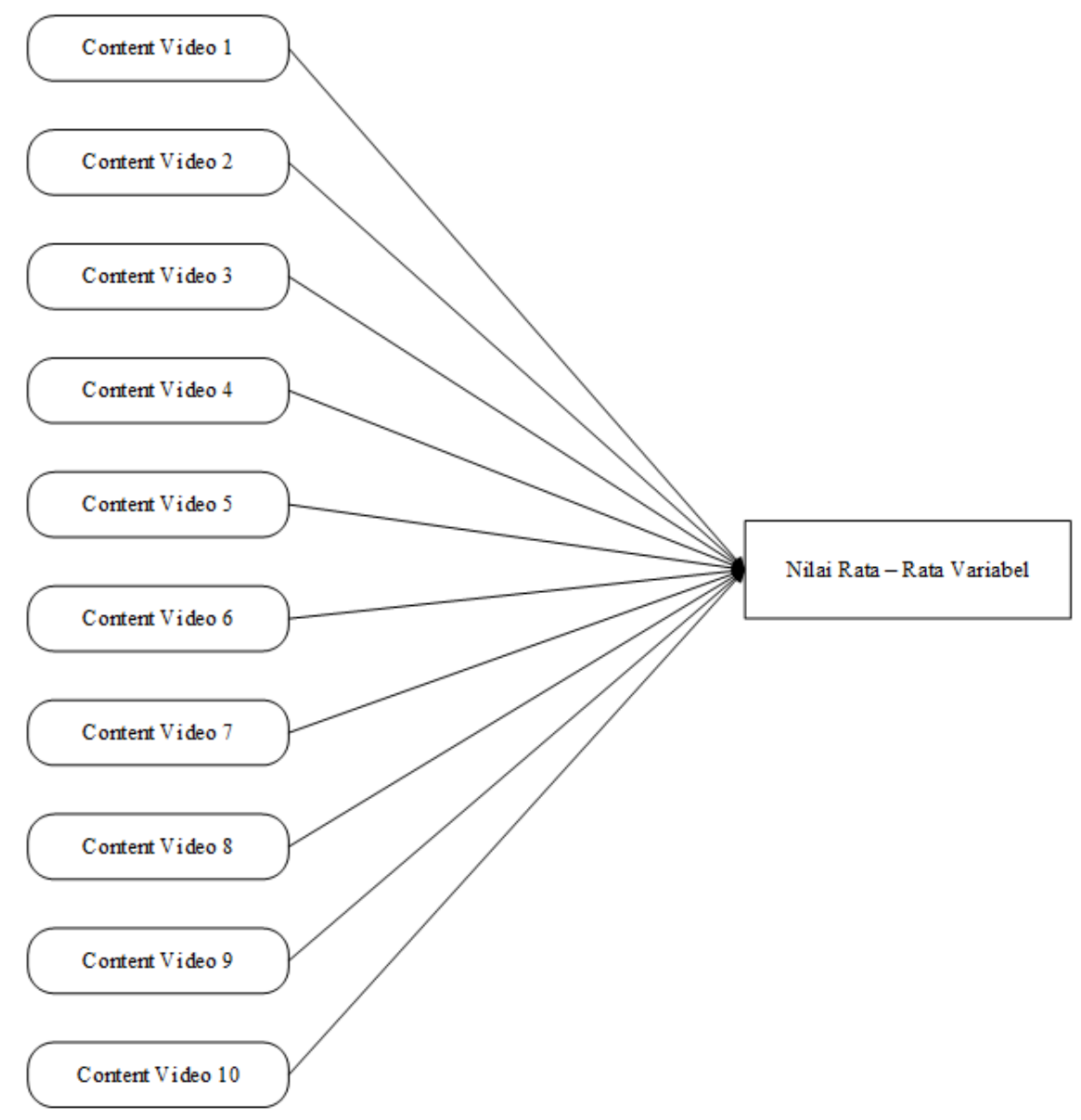

Gambar 3.1. Analisa Nilai Rata - Rata Pada Variabel.

\subsection{Menghitung Nilai Kredibilitas Rasio}

Langkah ketiga adalah menghitung nilai kredibilitas dari nilai variabel video share to nilai variabel video comments dengan menggunakan cara pembagian nilai variabel pertama yakni nilai variabel video share dengan nilai variabel kedua atau nilai variabel video comments. Sebagai contoh pada akun A, didapatkan nilai dari video share adalah 180 dan nilai dari video comments adalah 36, sehingga untuk mendapatkan nilai kredibilitas dilakukan dengan cara pembagian yaitu $180: 36=5$. Maka dapat diperlihatkan nilai dari nilai variabel video share to nilai variabel video comments pada akun A adalah 5.

\subsection{Menentukan Peringkat Pada Akun TikTok}

Langkah terakhir adalah melakukan penentuan peringkat dari masing - masing rasio yang sudah dihitung. Penentuan dilakukan dengan menggunakan karakteristik dari rasio yang didapatkan sehingga penentuan peringkat sesuai dengan kriteria yang diberikan. Terdapat dua jenis karakteristik yang diberikan, yaitu tinggi dan rendah. Pada jenis karakteristik rendah, objek atau variabel yang memiliki nilai variabel terendah akan diberikan nilai 5 sementara objek atau variabel yang memiliki nilai variabel tertinggi akan diberikan nilai 1. Sedangkan pada jenis karakteristik tinggi, objek atau variabel yang memiliki nilai variabel tertinggi akan diberikan nilai 5 
sementara objek atau variabel yang memiliki nilai variabel terendah akan diberikan nilai 1 . Kemudian nilai kredibilitas akan di lihat dan ditentukan peringkatnya sesuai dengan karakteristik yang didapatkan, maka dapat disimpulkan objek atau variabel mana yang akan mendapatkan peringkat 1 hingga peringkat 5 .

\section{HASIL DAN PEMBAHASAN}

Akun TikTok dari 5 Merek Smartphone Terlaris di Indonesia, diantaranya :

\section{Xiaomi Indonesia}

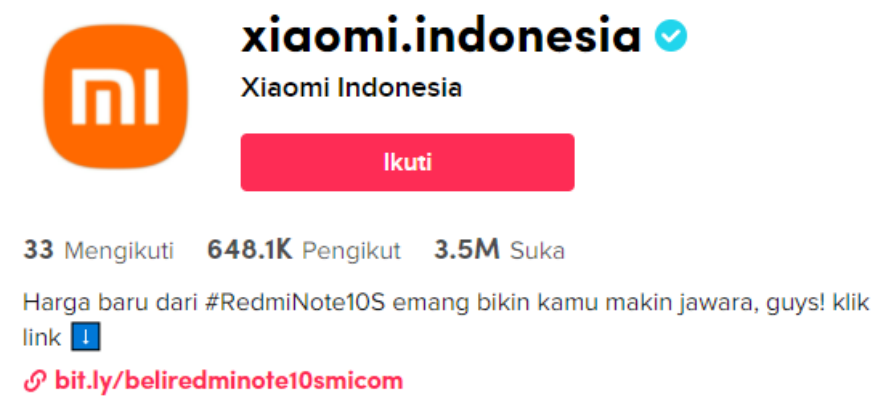

Gambar 4.1. Akun TikTok Xiaomi Indonesia

Sumber : https://www.tiktok.com/@xiaomi.indonesia? (akses pada 12-10-2021)

\section{Vivo Indonesia}

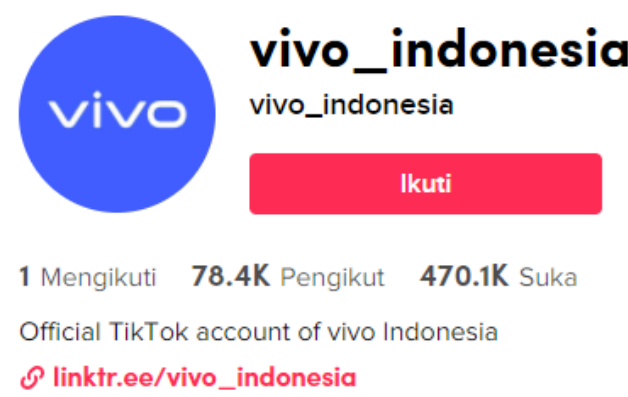

Gambar 4.2. Akun TikTok Vivo Indonesia 


\section{Oppo Indonesia}

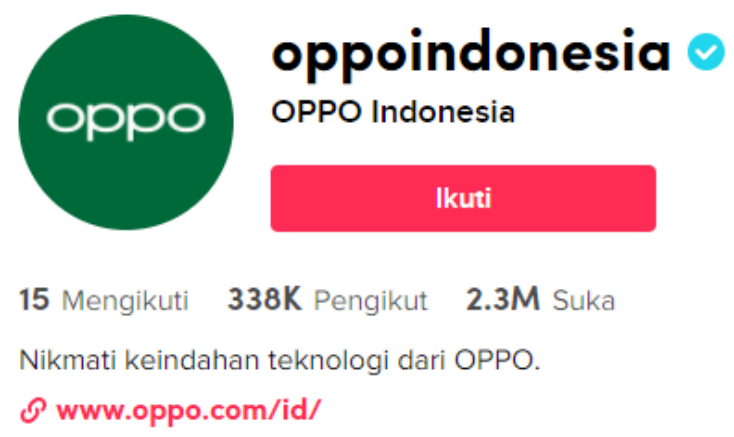

Gambar 4.3. Akun TikTok Oppo Indonesia

Sumber : https://www.tiktok.com/@oppoindonesia? (akses pada 12-10-2021)

\section{Samsung Indonesia}

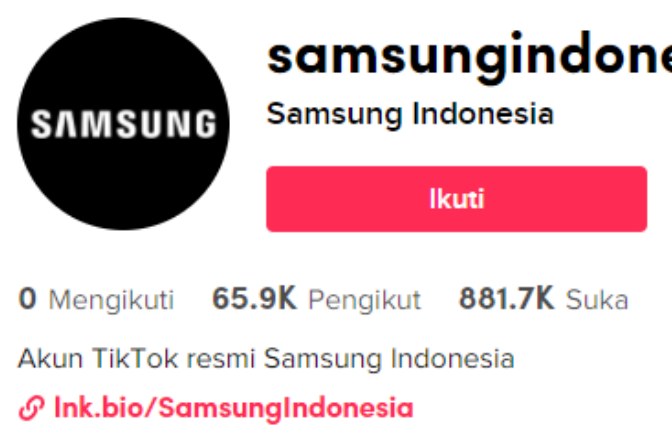

Gambar 4.4. Akun Tiktok Samsung Indonesia

Sumber : https://www.tiktok.com/@samsungindonesia? (akses pada 12-10-2021)

\section{Realme Indonesia}

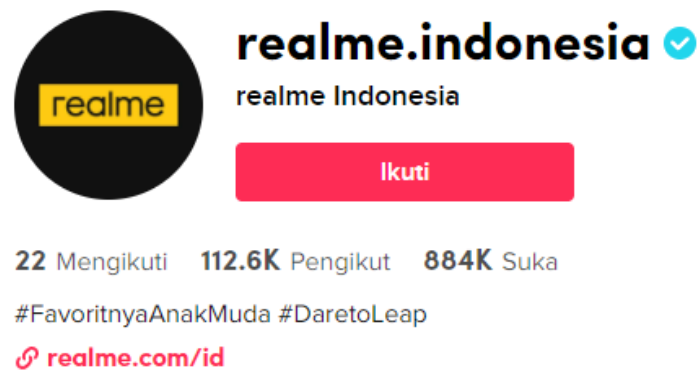

Gambar 4.5. Akun TikTok Realme Indonesia

Sumber : https://www.tiktok.com/@realme.indonesia? (akses pada 12-10-2021) 
Dari kelima akun Akun TikTok dari 5 Merek Smartphone Terlaris di Indonesia, peneliti menemukan nilai dari masing-masing variabel yang ada untuk menghitung rasio Video Share to Video Comments dari setiap akun. Pada akun TikTok terdapat 7 variabel, diantaranya yaitu:

1. Likes

2. Followers

3. Following

4. Video Likes

5. Video Comments

6. Video Share

7. Video Views

Dari ketujuh variabel tersebut peneliti hanya fokus untuk menemukan hasil dari 2 variabel, yaitu :

\section{Video Share \\ 2. Video Comments}

Dari kedua variabel tersebut kemudian dianalisa sehingga menemukan nilai rata-rata dari variabel video share dan variabel video comments. Untuk menghitung nilai rata-rata dari variabel video share dan variabel video comments yaitu dengan cara mengambil minimal 10 postingan kemudian di hitung sehingga menemukan nilai rata-rata dari masing-masing variabel. Berikut merupakan tabel nilai rata-rata dari masing-masing akun tiktok pada 5 merek smartphone terlaris di Indonesia, yaitu :

Tabel 4.1. Analisa Nilai Rata-Rata Nilai Variabel Video Share dan Video Comments Akun TikTok Xiaomi Indonesia

\begin{tabular}{|c|c|c|}
\hline \multicolumn{3}{|c|}{ Xiaomi Indonesia } \\
\hline No & Video Share & Video Comments \\
\hline 1 & 3 & 10 \\
\hline 2 & 97 & 27 \\
\hline 3 & 3 & 15 \\
\hline 4 & 18 & 28 \\
\hline 5 & 14 & 28 \\
\hline 6 & 5 & 3 \\
\hline 7 & 6 & 15 \\
\hline 8 & 137 & 29 \\
\hline 9 & 4 & 8 \\
\hline 10 & 1 & 7 \\
\hline Rata - Rata & $\mathbf{2 9}$ & $\mathbf{1 7}$ \\
\hline
\end{tabular}

Sumber : Pengolah Data Excel 
Tabel 4.2. Analisa Nilai Rata-Rata Nilai Variabel Video Share dan Video Comments Akun TikTok Vivo Indonesia

\begin{tabular}{|c|c|c|}
\hline \multicolumn{3}{|c|}{ Vivo Indonesia } \\
\hline No & Video Share & Video Comment \\
\hline 1 & 406 & 169 \\
\hline 2 & 145 & 11 \\
\hline 3 & 58 & 6 \\
\hline 4 & 68 & 1 \\
\hline 5 & 105 & 12 \\
\hline 6 & 658 & 81 \\
\hline 7 & 228 & 49 \\
\hline 8 & 40 & 11 \\
\hline 9 & 64 & 18 \\
\hline 10 & 23 & 2 \\
\hline Rata - Rata & $\mathbf{1 8 0}$ & $\mathbf{3 6}$ \\
\hline
\end{tabular}

Sumber : Pengolah Data Excel

Tabel 4.3. Analisa Nilai Rata-Rata Nilai Variabel Video Share dan Video Comments Akun TikTok Oppo Indonesia

\begin{tabular}{|c|c|c|}
\hline \multicolumn{3}{|c|}{ Oppo Indonesia } \\
\hline No & Video Share & Video Comment \\
\hline 1 & 115 & 9 \\
\hline 2 & 383 & 149 \\
\hline 3 & 148 & 21 \\
\hline 4 & 168 & 14 \\
\hline 5 & 129 & 2 \\
\hline 6 & 102 & 14 \\
\hline 7 & 103 & 6 \\
\hline 8 & 165 & 13 \\
\hline 9 & 211 & 29 \\
\hline 10 & 193 & 27 \\
\hline Rata - Rata & $\mathbf{1 7 2}$ & $\mathbf{2 8}$ \\
\hline \multicolumn{3}{|c|}{ Sumber : Pengolah Data Excel } \\
\hline
\end{tabular}


Tabel 4.4. Analisa Nilai Rata-Rata Nilai Variabel Video Share dan Video Comments Akun TikTok Samsung Indonesia

\begin{tabular}{|c|c|c|}
\hline \multicolumn{3}{|c|}{ Samsung Indonesia } \\
\hline No & Video Share & Video Comment \\
\hline 1 & 0 & 0 \\
\hline 2 & 3 & 5 \\
\hline 3 & 225 & 75 \\
\hline 4 & 9 & 4 \\
\hline 5 & 21 & 4 \\
\hline 6 & 324 & 74 \\
\hline 7 & 283 & 73 \\
\hline 8 & 473 & 117 \\
\hline 9 & 7 & 0 \\
\hline 10 & 535 & 108 \\
\hline Rata - Rata & $\mathbf{1 8 8}$ & $\mathbf{4 6}$ \\
\hline \multicolumn{2}{|c|}{ Sumber : Pengolah Data Excel } \\
\hline \multicolumn{2}{|c|}{} \\
\hline
\end{tabular}

Tabel 4.5. Analisa Nilai Rata-Rata Nilai Variabel Video Share dan Video Comments Akun TikTok Realme Indonesia

\begin{tabular}{|c|c|c|}
\hline \multicolumn{3}{|c|}{ Realme Indonesia } \\
\hline No & Video Share & Video Comment \\
\hline 1 & 13 & 20 \\
\hline 2 & 4 & 15 \\
\hline 3 & 28 & 26 \\
\hline 4 & 9 & 9 \\
\hline 5 & 26 & 16 \\
\hline 6 & 27 & 14 \\
\hline 7 & 45 & 51 \\
\hline 8 & 55 & 57 \\
\hline 9 & 10 & 20 \\
\hline 10 & 38 & 17 \\
\hline Rata - Rata & $\mathbf{2 6}$ & $\mathbf{2 5}$ \\
\hline \multicolumn{2}{|c|}{ Sumber : Pengolah Data Excel } \\
\hline
\end{tabular}


Setelah menghitung nilai rata-rata tersebut, maka akan menemukan hasil akhir nilai rata-rata dari variabel video share dan video comments, berikut hasil akhirnya :

Tabel 4.6. Nilai Variabel Pada Akun TikTok 5 Merek Smartphone Terlaris di Indonesia

\begin{tabular}{|c|c|c|c|c|c|}
\hline Variable & $\begin{array}{c}\text { Xiaomi } \\
\text { Indonesia }\end{array}$ & $\begin{array}{c}\text { Vivo } \\
\text { Indonesia }\end{array}$ & $\begin{array}{c}\text { Oppo } \\
\text { Indonesia }\end{array}$ & $\begin{array}{c}\text { Samsung } \\
\text { Indonesia }\end{array}$ & $\begin{array}{c}\text { Realme } \\
\text { Indonesia }\end{array}$ \\
\hline Video Share & 29 & 180 & 172 & 188 & 26 \\
\hline $\begin{array}{c}\text { Video } \\
\text { Comments }\end{array}$ & 17 & 36 & 28 & 46 & 25 \\
\hline
\end{tabular}

Sumber : Pengolah Data Excel

Pada akun TikTok terdapat 17 rasio yang relevan digunakan untuk mengukur kredibilitas pada masing-masing akun. Namun pada penelitian kali ini hanya berfokus untuk menghitung Video Share to Video Comments Ratio. Untuk menghitung kredibilitas dari masing-masing akun TikTok setiap merek smartphone, peneliti menghitung dengan cara : variabel 1 akan dibagi dengan variabel 2 , sehingga ditemukan hasil analisisa dari rasio tersebut.

Tabel 4.7. Hasil Perhitungan Rasio Akun TikTok

\begin{tabular}{|c|l|c|c|c|c|c|}
\hline No & \multicolumn{1}{|c|}{ Ratio } & $\begin{array}{c}\text { Xiaomi } \\
\text { Indonesia }\end{array}$ & $\begin{array}{c}\text { Vivo } \\
\text { Indonesia }\end{array}$ & $\begin{array}{c}\text { Oppo } \\
\text { Indonesia }\end{array}$ & $\begin{array}{c}\text { Samsung } \\
\text { Indonesia }\end{array}$ & $\begin{array}{c}\text { Realme } \\
\text { Indonesia }\end{array}$ \\
\hline \multirow{2}{*}{1} & $\begin{array}{l}\text { Video Share to } \\
\text { Video Comments } \\
\text { Ratio }\end{array}$ & $\begin{array}{c}1,6941176 \\
47\end{array}$ & 4,9861111 & 6,0457746 & 4,0869565 & 1,0408163 \\
27 & 48 & 22 & 27 \\
\hline
\end{tabular}

Sumber : Pengolah Data Excel

Video Share to Video Comments Ratio memiliki karakteristik yang tinggi, artinya semakin tinggi nilai yang dihasilkan maka semakin baik kredibilitas dari performa akun tersebut. Untuk memberikan peringkat pada masing-masing merek Smartphone, peneliti memberikan angka 5 kepada merek yang mendapatkan nilai tertinggi dan angka 1 untuk merek smartphone yang mendapatkan nilai terendah. Berikut merupakan tabel urutan nilai yang dihasilkan oleh masingmasing merek smartphone. 
Tabel 4.8. Nilai Rasio Akun TikTok 5 Merek Smartphone Terlaris di Indonesia

\begin{tabular}{|c|c|c|c|c|c|}
\hline \multirow{2}{*}{\multicolumn{1}{|c|}{$\boldsymbol{R A T I O}$}} & \multicolumn{5}{|c|}{ NILAI } \\
\cline { 2 - 6 } & $\begin{array}{l}\text { Xiaomi } \\
\text { Indonesia }\end{array}$ & $\begin{array}{l}\text { Vivo } \\
\text { Indonesia }\end{array}$ & $\begin{array}{l}\text { Oppo } \\
\text { Indonesia }\end{array}$ & $\begin{array}{l}\text { Samsung } \\
\text { Indonesia }\end{array}$ & $\begin{array}{l}\text { Realme } \\
\text { Indonesia }\end{array}$ \\
\hline $\begin{array}{l}\text { Video Share to Video } \\
\text { Comments Ratio }\end{array}$ & 2 & 4 & 5 & 3 & 1 \\
\hline
\end{tabular}

Sumber : Pengolah Data Excel

Dari Tabel Nilai Rasio Akun TikTok 5 Merek Smartphone Terlaris di Indonesia dapat disimpulkan bahwa Oppo Indonesia mendapatkan nilai tertinggi untuk rasio Video Share to Video Comments. Sedangkan akun TikTok Realme Indonesia mendapatkan nilai terendah untuk rasio ini. Jadi, pada penelitian ini Oppo Indonesia memiliki kredibilitas performa yang lebih baik dibandingkan dengan merek smartphone yang lainnya.

\section{KESIMPULAN}

Tujuan dari penelitian ini adalah mengetahui kredibilitas performa dari Akun TikTok 5 Merek Smartphone Terlaris di Indonesia menggunakan Video Share to Video Comments Ratio. 5 Merek Smartphone Terlaris di Indonesia tersebut diantaranya : Xiaomi Indonesia, Vivo Indonesia, Oppo Indonesia, Samsung Indonesia, dan Realme Indonesia. Dari kelima merek smartphone tersebut dapat disimpulkan bahwa :

1. Peringkat pertama diraih oleh merek Oppo Indonesia dengan nilai tertinggi yaitu 6,045774648

2. Peringkat kedua diraih oleh merek Vivo Indonesia dengan nilai 4,986111111

3. Peringkat ketiga diraih oleh merek Samsung Indonesia dengan nilai 4,086956522

4. Peringkat keempat diraih oleh merek Xiaomi Indonesia dengan nilai 1,694117647

5. Peringkat kelima diraih oleh merek Realme Indonesia dengan nilai terendah yaitu 1,040816327 


\section{DAFTAR PUSTAKA}

“Daftar 5 Merek Smartphone Terlaris Di Indonesia, Xiaomi Nomor 1.” 2021.

Https://Www.Suara.Com/. October 2021.

https://www.suara.com/tekno/2021/10/03/133108/daftar-5-merek-smartphone-terlarisdi-indonesia-xiaomi-nomor-1.

Dewa, Chriswardana Bayu, and Lina Ayu Safitri. 2021. "Pemanfaatan Media Sosial Tiktok Sebagai Media Promosi Industri Kuliner Di Yogyakarta Pada Masa Pandemi Covid-19 (Studi Kasus Akun TikTok Javafoodie).” Khasanah Ilmu - Jurnal Pariwisata Dan Budaya 12 (1). https://doi.org/10.31294/khi.v12i1.10132.

Firamadhina, Fadhlizha Izzati Rinanda, and Hetty Krisnani. 2021. "PERILAKU GENERASI Z TERHADAP PENGGUNAAN MEDIA SOSIAL TIKTOK: TikTok Sebagai Media Edukasi Dan Aktivisme." Share : Social Work Journal 10 (2): 199. https://doi.org/10.24198/share.v10i2.31443.

I Putu Hendika Permana, and Ni Putu Suci Meinarni. 2021. "Ratio Analysis on Tiktok (Social Media) for Qualitative Research Using Explorative Methods." Jurnal Ekonomi \& Bisnis JAGADITHA 8 (1): 30-38. https://doi.org/10.22225/jj.8.1.2944.30-38.

Kesuma, Steven, and Daniel Tamburian. 2021. "Resepsi Remaja Terhadap Konten @BotakTikTok Di Media Sosial TikTok.” Koneksi 5 (1): 182. https://doi.org/10.24912/kn.v5i1.10228.

Khanifah, Laily Nur, (2021). 2021. "PERAN STRATEGI DIGITAL MARKETING PADA SOSIAL MEDIA (TIK-TOK).” http://repository.untag-sby.ac.id/id/eprint/9439.

Mudjiyanto, Bambang. 2018. "TIPE PENELITIAN EKSPLORATIF KOMUNIKASI." Jurnal Studi Komunikasi Dan Media 22 (1): 65. https://doi.org/10.31445/jskm.2018.220105.

Oktaheriyani, Desy, M Ali Wafa, and Shen Shadiqien. 2020. "MEDIA SOSIAL TIKTOK ( Studi Pada Mahasiswa Fakultas Ilmu Sosial Dan Ilmu Politik UNISKA MAB Banjarmasin )." Skripsi Ini Mah. http://eprints.uniska-bjm.ac.id/id/eprint/3504.

Priatama, Ryan, Ilham Hilal Ramadhan, Az- Zuhaida, Awanis Akalili, and Febriansyah Kulau. 2021. "ANALISIS TEKNIK DIGITAL MARKETING PADA APLIKASI TIKTOK (Studi Kasus Akun TikTok@jogjafoodhunterofficial).” SOCIA: Jurnal IlmuIlmu Sosial 18 (1): 49-60. https://doi.org/10.21831/socia.v18i1.40467.

Rahardaya, Astrid Kusuma, and Irwansyah Irwansyah. 2021. "Studi Literatur Penggunaan Media Sosial Tiktok Sebagai Sarana Literasi Digital Pada Masa Pandemi Covid-19.” Jurnal Teknologi Dan Sistem Informasi Bisnis 3 (2): 308-19. https://doi.org/10.47233/jteksis.v3i2.248.

Riadi, Muchlisin. 2020. "Pengertian Dan Jenis-Jenis Variabel Penelitian." Kajianpustaka.Com. 2020. https://www.kajianpustaka.com/2020/09/pengertian-danjenis-variabel-penelitian.html. 